\title{
CORRESPONDENCE
}

\section{THE CAMBRIAN ROCKS OF ARVON}

Sirs,- In my "Cambrian Rocks of Arvon", (Geol. Mag., lxxxi, 1944, p. 170) under the heading Greywackization, I might with advantage also have cited my own paper on the Harlech Grits (Trans. Edinb. Geol. Soc., 1897) since, in that, there were studies as well of crystalline structures.

AETHWy Ridge, Bangor.

E. Greenly. 2nd October, 1944.

\section{GLACIATION OF CORNDON}

SIR,-In his reply to Dr. G. Slater's contribution to the discussion on his paper on "Intrusive Rocks of the Shelve Area" (Quart. Journ. Geol. Soc., c, 1944, p. 164), Dr. F. G. H. Blyth mentions fig. 8 of The Welsh Borderland in support of his opinion that " it is unlikely that the summit of Corndon was covered by the Pleistocene ice". In thus citing this figure Dr. Blyth gives it an authority it was not intended and does not deserve to bear. It was intended merely to illustrate, in a generalized and composite manner, the distribution of ice-sheets and trends of icemovement in the Welsh Border region. In compiling it I was largely dependent, for the area south of the Shrewsbury Sheet of the geological map, upon the paper by A. R. Dwerryhouse and A. A. Miller in the Quarterly Journal of the Geological Society for 1930. This paper, unfortunately, was not accompanied by any map of the glacial deposits and, so far as I am aware, no such map of the country around Corndon has ever been published.

This caveat, however, should not be taken as implying any disagreement with Dr. Blyth's opinion that the summit of Corndon was probably not covered by the ice. Even if it was covered at the maximum it must have become bare at a relatively early stage of the deglaciation, for the development of Marrington Dingle as a marginal channel shows that the whole "Shelve country" must have been ice-free when the Camlad and Severn valleys were still choked with ice.

Incidentally, without implying any disparagement of the pioneer work of Dwerryhouse and Miller, a detailed study of the drifts of the Shelve country and of their relation to those of the Camlad, Marton, and Severn valleys, may be commended to glacial geologists as a piece of work likely to produce rewarding results.

\footnotetext{
Geological Survey and Museum,

EXHIBITION ROAD,

SOUTH KeNSINGTON,

LONDON, S.W. 7.

9th August, 1944.
}

TALbot H. WhiteheAd. 